\title{
Determination the therapeutiction of Datura metel leaves extract for some urinary system bacteria in rabbits (in vitro and in vivo )
}

\author{
H. K.Al-Mosoy \\ Coll. of Scie. / Univ. of Al-Muthanna
}

\begin{abstract}
This study was designed to evaluate the effects the watery and alcoholic extracts from leaves of Datura metel in vitro to ten of pathogenic bacteria and study the watery extract toward Candida on urinary system in rabbits. The results showed the watery and alcoholic extracts from leaves of Datura metel have antibacterial activity against both Gram positive (Staphylococcus. aureus - Streptococcus agylactiae) And Gram negative bacteria (Klebsilla. pneumonia Proteus. vulgaricus - E.coli - Pseudomonas - Vibrio - Salmonella - Enterobacter ) and Candida. albicans however the watery extract of Datura metel were more potent than alcoholic extract against pathogenic bacteria $(80 \%)$. According to results, Candida pathogen that more sensitive to ward Datura metel watery extract was choosing to injected intraperitonialy as experimental infection in laboratory animals (vivo) which cause morphological and histopathological degenerative lesion of kidney cortex and medulla tissue in addition to change of renal profile test that include blood urea nitrogen, creatinine, creatinine kinase, uric acid, in addition to Potassium. but after watery extract of Datura metel injected in these laboratory animals cause significant improvement $(\mathrm{p} \leq 0.01)$ in the value of blood urea nitrogen, creatinine, creatinine kinase and uric acid. Potassium concentration, histopathological studies confirm these results which include regeneration of degenerative lesion for medulla and kidney cortex with convoluted tubules tissue.
\end{abstract}

\section{Introduction}

Despite widespread use of synthetic chemicals for the control of diseases, recent awareness about their adverse side effects prompted the use of environmentally acceptable alternative method for disease control. The approaches that are presently being persuaded are biological control, gentic engineering, use of systemic acquired resistance (SAR) with the help of biotic and abiotic agents [1]. And importantly, the use of biodegradable natural products, especially from medicinal plants [2]. Crude as well as ethanolic extract of some plant extracts including Datura sp. Have been tested by many workers for their efficacy against several pathogenic fungi in vitro.Datura metel L. is a sub-glabrous shrubby herb which belongs to the family Solanaceae and grows throughout India. The dried leaves of the plant have long been known in India for their narcotic and anti-spasmodic properties[3]. And these activities are considered to be due to scopolamine and other tropine alkaloid present in the plant. While the presence of alkaloid in D. metel leaves has been for a long time, it was rather recently that a novel steroid, withametelin, was isolated from this source as a major constituent [4].Leaf extract of D.metel has been reported to exhibit plant virus inhibiting properties [5] [6]. They have also been assayed against spore germination of Alternaria alternate Drechslera halodes and Helminthosporium speciferum [7].In view of this work . it was considered worthwhile to evaluate the therapeutic activity of Datura metel against some G+ and G- bacteria and Candida fungi.

\section{Materials \& Method}

\section{Part I}

Collection of Datura metel leaves plant

Plant material, leaves of Datura metel, was obtained from the house garden from 
the period 15 December to 15 April after cleaning the leaves from the dust; they put in oven to dry then crushed to produce powdered material .

\section{Preparation of plant extracts}

\section{1- watery extract}

$50 \mathrm{~g}$ of powdered plant was taken and added to $500 \mathrm{ml}$ of distilled water then placed in a water bath has $45 \mathrm{CO}$ (for four hours) and shake well, the suspension was filtered with a piece of cloth (muslin), and then left to dry on sterile crucible, later the solid layer of the dishes was eliminated using sharp material and convert it to powder for preparation different concentration [8].

\section{2- preparation of cold alcoholic extract}

The extraction was applied as in [9] method, about $500 \mathrm{ml}$ of ethanol alcohol in concentration of $80 \%$ was added to $50 \mathrm{gm}$ of Datura metel plant powder, the mixture was placed in closed bottle, after 24 hours the bottle content was filtered by a piece of cloth (muslin), the filtered material left to dry and convert it to powder for preparation different concentration 50-75-100\%.[10].

\section{Preparation of bacterial suspension}

Special bacterial suspension from (Pseudomonas - Staphylococcus aureus Klebsilla pneumoni - Proteus vulgaricus Streptococcus agylatiae - Escherichia. coli Enterobacter- Vibrio - Salmonella Candida albicans ) were prepared on Muller Hinton Broth and incubated at $37 \mathrm{CO}$ for 24 hours, Then 1 micron was taken from each bacterial suspension and diffused on Muller Hinton agar By using L-shape spreader ,the plates were left for about 5-10 minute to permit the suspension for drying on the agar. Then 3 equal distant wholes were mode inside the plates for putting different plant extract concentration 50-75$100 \%$ Plates were incubated at 37CO for 24 hours; the effect of plant extract on bacteria was calculated by Minimum Bactericidal Concentration (MBC) around the different concentration wholes [11].

\section{Part II}

\section{1- Animals}

Clinically healthy six month old white new Zealand rabbits were used in the experiment (rabbits are divided to tow groups control group administrated food and tap water and injected with 10-5 Candida suspension (as this yeast consider the more susceptible to this plant extract ) intraperitonially and treatment group T2 administrated food and tap water and injected with 10-5 Candida supension intraperitonially to induce respiratory pneumonia then injected with alcoholic extract of Datura metel, after 36 hrs. for injection, plant extract was administrated intraperitonially in the form of two dose 500 mg daily for three weeks.

\section{2- Sample collection}

At 10 weeks whole blood was collected via cardiac puncture from anaesthetized (ketamine $50 \mathrm{mg} / \mathrm{kg}$-xylazine $10 \mathrm{mg} / \mathrm{kg}$ ), rabbit were then euthanized with a single cardiac injection fatal plus (concentrated pentobarbital, $360 \mathrm{mg} / \mathrm{kg}$ ), and kidney tissues was collected for histological studies.

\section{Blood chemistries}

Blood urea nitrogen, creatinine, creatinine kinase, uric acid and calcium concentration in plasma were determined using commercially available kit (sigma)

\section{Statistical analysis}

Mean \pm SE was used to describe variables. All data are analyzed using Duncan's multiple range test to determine if the treatment were significantly $(\mathrm{P} \leq 0.01)$ different or not [12] .

\section{Results}

The results illustrated indicated that the two crude extracts from the leaves of Datura metel showed antibacterial activity against some pathogenic Bactria . however the crude extract of Datura metel were more potent antibacterial pathogenic bacteria appear more resistant for all watery extract and all alcoholic extract for Datura metel 


\section{$\begin{array}{llll}\text { AL-Qadisiya Journal of Vet.Med.Sci. } \quad \text { Vol./12 No./1 } & \text { No13 }\end{array}$}

leaves, these results did not occupied with [8], while results related with Candida appear high sensitivity for $50-75 \%$ concentration of watery extract about $3 \mathrm{~cm}, 2.5 \mathrm{~cm}$ respectively , while watery extract $100 \%$ concentration and alcoholic extract $50 \%$ concentration Table 1 refer to sentevty of Different Kinds of Bacteria toward D.metel leaves extracts (MBC) .

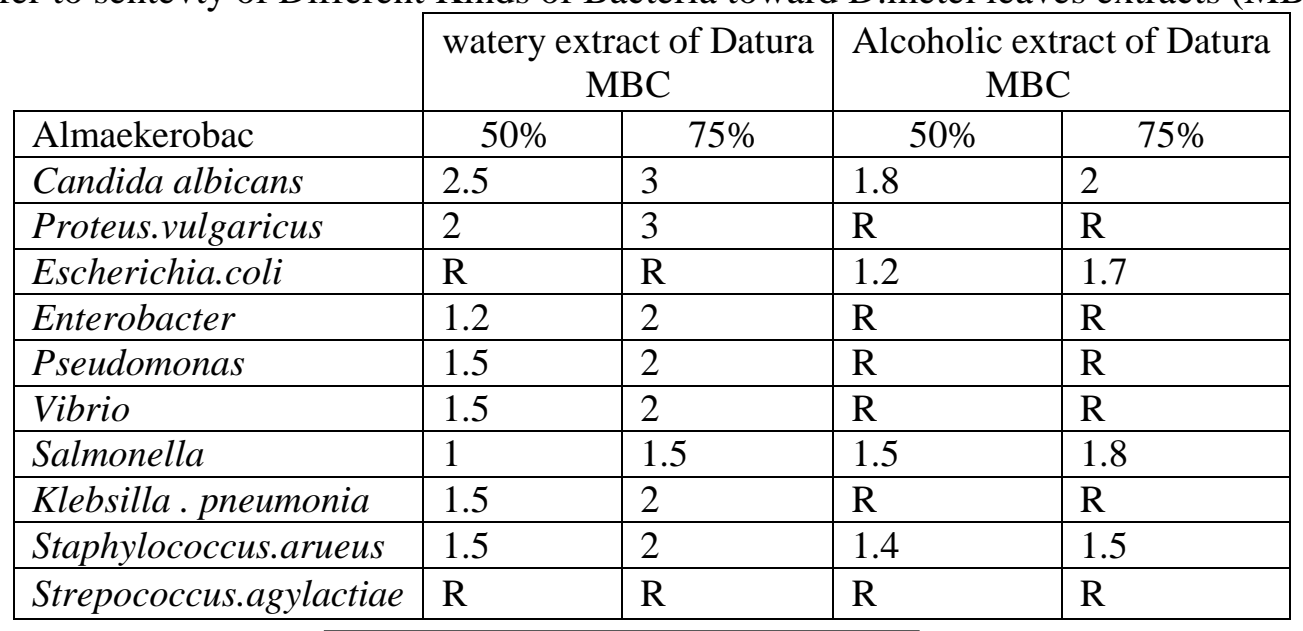

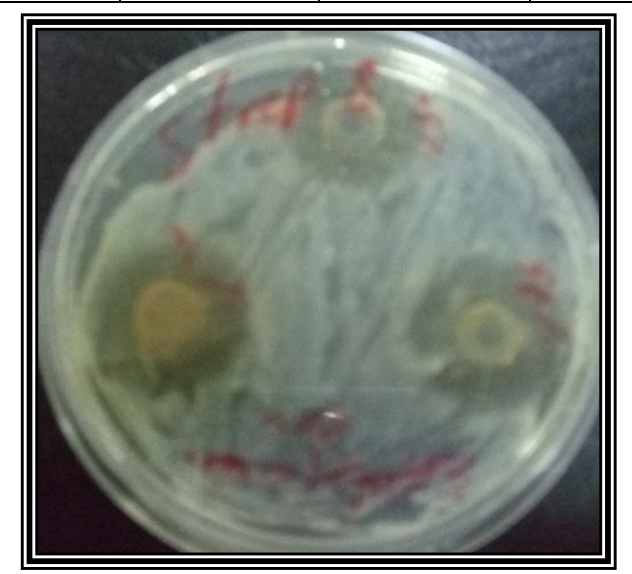

Fig 1 is appear sensitivity of Candida albicans toward watery leaf extract of Datura metel

Fig is appear sensitivity of streptococcus pneumonia toward alcoholic leaf extract. This bacteria was selected to inject intraperitonially then treated with watery extract for Datura metel leaves after 36 hrs from injection.Results in vivo indicate presence of Table (1) indicate the effect of Datura metel leaves on renal profile test for infected rabbits with Candida

\begin{tabular}{|l|ll|ll|}
\hline Renal profile test & G1 animals & G2 animals & \\
\hline blood urea nitrogen & $53.6 \pm 1.019$ & a & $38 \pm 0.909$ & b \\
\hline Creatinine & $1.226 \pm 0.045$ & a & $0.805 \pm 0.009$ & b \\
\hline creatinine kinase & $439.9 \pm 10.488$ a & $182.98 \pm 23.348$ & b \\
\hline uric acid & $3.55 \pm 0.105$ & a & $2.25 \pm 0.068$ & b \\
\hline Potassium & $4.671 \pm 0.299$ & a & $3.757 \pm 0.065$ & b \\
\hline
\end{tabular}

Results are expressed as mean \pm standard error.

a: no significant variation

Different letters between groups refer to significant variation under $(\mathrm{p}<0.01)$.

Degree of freedom $: 1,9$ 
These results are supported by histopathological examination Results indicates presence of inflammatory area (spots or patches) in the cortex and medella of kidney, increase the numbers of cells in the wall of proximal and distal convoluted tubules, with enlargement of the cells in the wall of collecting duct and distal convoluted tubules, hypertrophy of bowman capsule, mononuclear cells present in the interstitial space between renal tubules, damage in cilia for G1 animals as present in fig 1 and fig 2
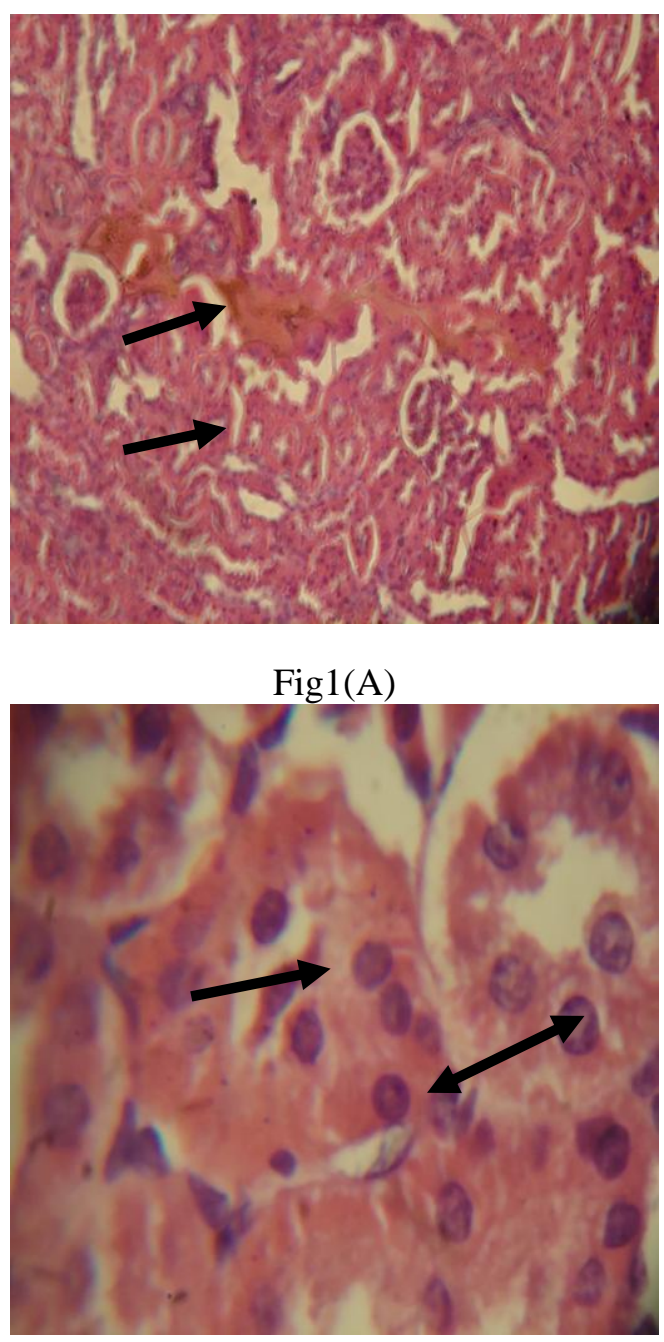

Fig 1 (B)

Photomicrographs of haematoxylin and eosin stained sections of rabbit kidney; (A\&B) presence of inflammatory area (spots or patches) in the cortex and medella of kidney, increase in the wall of proximal and distal convoluted tubules, with enlargement of the cells in the wall of collecting duct and distal convoluted tubules, hypertrophy of bowman capsule, presence of mononuclear cells in the interstitial spaces between renal tubules damage in cilia. (A:H\&E, 10x, $B: H \& E, 100 \times)$.

Histopathological examination for G2 animals reveal moderate regeneration for cells of collecting ducts, proximal and distal convoluted Histopathological examination for G2 animals reveals moderate regeneration for cell of collecting ducts , proximal and distal convoluted tubules and disappearance of congestion in the interstitial spaces for kidney corbex as explained in fig 2 (AandB). 


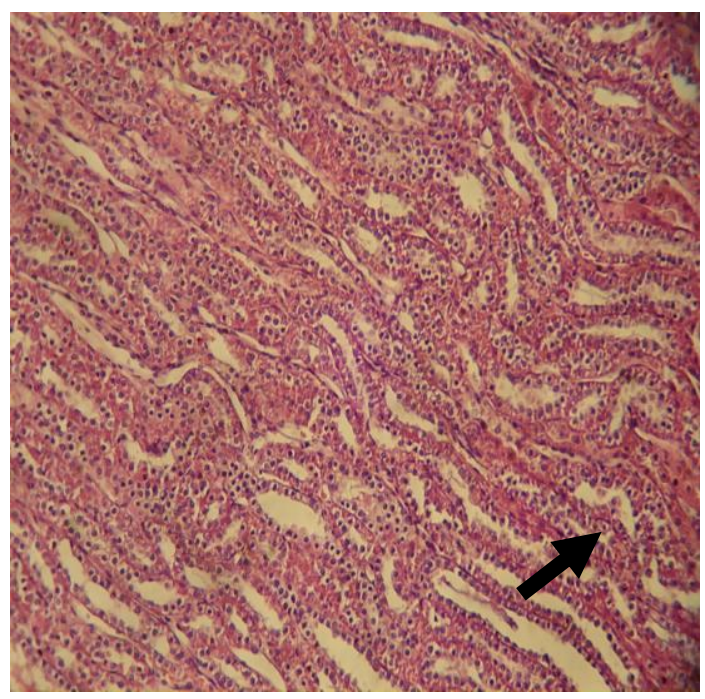

Fig 2(A)

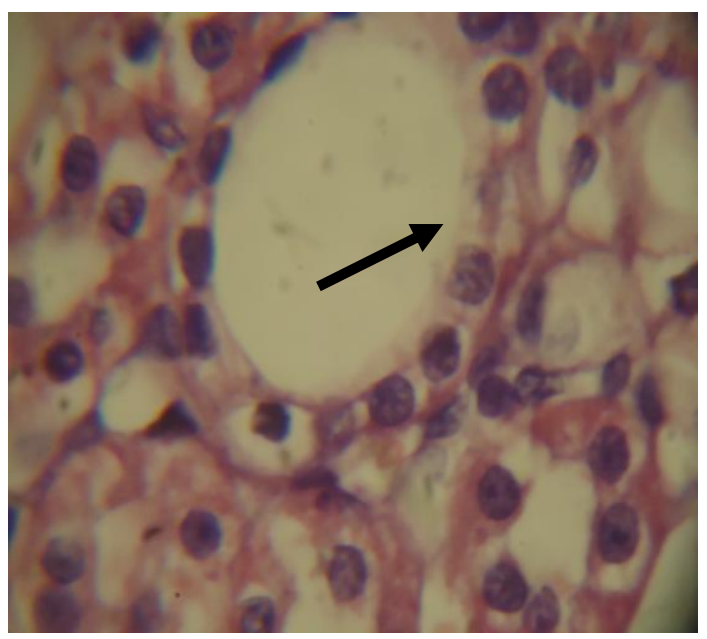

Fig 2 (B)

Photomicrographs of haematoxylin and eosin stained sections of rabbit kidney; $(\mathrm{A} \& \mathrm{~B})$ presence of reveal moderate regeneration for cells of collecting ducts, proximal and distal convolted tubules, disappearance of congestion in the interstitial spaces for cortex of kidney. (A:H\&E, 10×, B:H\&E, 100×).

\section{Discussion}

Anti-biotic was medical miracles during the second world but are now becoming impotent bacterial weaponry. This has caused an urgent need for the search of new and innovative ways to control bacterial invasions especially by multi-resistant pathogens [13].Natural alternative treatment for bacterial infection may provide pathway for the development of new antimicrobial agents, This study indicated that watery and alcoholic extracts for Datura metel leaves were more potent against Gram positive than Gram negative bacteria, in addition to its antifungal effect, this may be due to chemical composition for Datura metel that contain withametelin and. withanolide that have antifungal activity which isolated from Datura metel for therapeutic activity .[14],[15],[16].Our results refer to degenerative change in kidey of G2 group as 
supported by histopathological lesions in there cortex and medulla, kidney is one of multiple organ affected by sepsis. Sepsis is the leading cause of acute renal failure which mostly develops as part of a spectrum of organ dysfunction candida induce renal dysfunction, especifically glomerular filtration is impaired, as shown by a significant increase in the level of urea and uric acid [17]. Our data also reveal that serum creatinine and creatinine kinase levels were significantly higher than normal level, creatinine is a small and freely filtered solute by the glomeruli of the kidney. Crn is produced from the breakdown of creatinine in muscle while creatinine kinase mostly reveal presence of damage for heart tissue which an indicator for presence of multiple organ dysfunction.as occur in Ip candida injection. A reduced glomerular filtration rate (GFR) leads to retention of $\mathrm{Crn}$ in the blood. If we assume that $\mathrm{Crn}$ is produced at a constant rate in an individual, then a 50 percent reduction in GFR results in proximate doubling of the plasma Crn concentration [18] These data indicate that animals suffered from infections and kidney damage, while data for $\mathrm{G} 2$ animals represent significant improvement this may be due to therapeutic effect of Datura metel leave watery extract on this fungi.Results also refer to significance $(\mathrm{p} \leq 0.0 .1)$ decrement in the levels of other renal profile test, ( uric acid, BUN and potassium ion ) for G2 animal group than G1 animal group . this reporting evidence of decreed nephrotocity for G2 group .high levels of renal profile test

for G1 animal group associated with rapidly deteriorating Renaldo, dysfunction particularly when associated with multiorgan failure [19]. As accurse with IP Candida injection, withametelin and awithanolide showed significant antifungal activity against all fungi at maximum concentration (1000 ppm) steroid [20]. Steroidal compounds of plant origin are reported to be antifungal. They affect spore germination and germ- tube elongation[21]. Steroidal saponins isolated from the bulbs of Allium ampelosperasum exhibited antifungal activity candida albicans . Polar steroidal glycosides and steroidal glycosides from the stem bark of Holarrhena floribundai were effective against Candida albicans .there steroids exhibited antifungal activity against Candida albicans [22]. Several species of Datura are reported to contain antifungal properties in their crude extracts. Earlier studies indicate that D.alba and D.stramonium are inhibitory against several fungi [23].[24]. Aqueous leaf extract of D. metel has already been reported to inhibit the growth of Pyricularia grisea and $\mathrm{H}$ elminthosporium oryzae [25]. Though previous results indicate that Datura contains potential antifungal compound(s) effective against a wide range of plant pathogenic as well as saprophytic fungi, the present results of antifungal activity of withametelin.a steroidal compound isolated from leaves of D.metel is being reported its efficacy at a very low concentration futher indicates a possibility of its use against plant diseases under field conditions [16].

\section{Reference}

1. Morton, J. F. (1981). Atlas of Medicinal Plants of Middle America, (1st) ed, Pp: 76-78

2. Melendez, E. N. (1982). Plantas medicinales de Puerto Rico: folklorey fundamentos cientificos, RioPiedras, PR,Editorial de la Unversidad de Puerto Rico.Pp: Pp: 65-89.
3. Cowan, M. M. (1999). Plant products as antimicrobial agents. Clin Microbiol Rev. 12:564-582

4. Mitchell, S.A. and Ahmad, M. H. (2006).A Review of Medicinal Plant Research at the University of the West Indies, Jamaica, 19482001. West Indies Medical Journal 55:243-269 
$\begin{array}{llll}\text { AL-Qadisiya Journal of Vet.Med.Sci. } & \text { Vol./12 } & \text { No./1 }\end{array}$

5. Singh, I and Varma, J. p. 1981. Virus inhibitor from Dature metel. Indian phytopathol . 34:452

6. Verma. H.N.and Mukerjee, K. 1979. Induction of antiviral resistance phytophathol. 32:95.

7. Srivastava, A.and Srivastava, M. 1998. Fungitoxic effect of some medicinal plants (on some fruit pathogens ). Philippine J. Sci. 127:181-187.

8. Mansouri, S., Foroumadi, A., Ghaneie, T. and Ahmad, G. N. (2001). Antibacterial activity of the crude extracts and fractionated constituents of Myrtus communis. Pharma Biol (39):399-401.

9. Harborne J.b .(1991). The chemical basis of plant defense Against Mmmalian Herbivory .(eds. Palo ,R.T. and Robbins,C.T), CRC press,Newyork.,pp.45-59.

10. Gilman, E. F. and Watson , D.G.(2006).ENH271, One of series of the environmental Horiticulture Department, floride cooperative extension service, institute of food and Agricultural Sciences, Unversity of floridia., Pp: 93- 103.

11. Lamia , T. ; Bousselmi , K. ; Saida B , R. and Allah , M.A(2007). Epiderniological profile and antibiotic susceptibility of Pseudomonas aeruginosa isolated with in burned patient hospitalized in the intensive care burn unit. Tunis Med. 85(2) : 124-127.

12. Duncan, B. D. (1955). Multiple range and multiple $\mathrm{F}$ test. Biometrics.11:1-42

13. Lewis, R. (1995). The rise of antibiotic resistant infection. FDA Consumer Magazine. Retrieved from: http :// www.fda.gov ? Fdac /features , 795- 799 .antibio.html.

14. Oyedeji, O. O., Lawai, O. A., Shade, F. O. and Oyedeji, A. O. (2009).Chemical composition of antibacterial activity of the essential oils of Callistemon viminalis from South Africa. Molecules (14):19901998.

15. Lamia, T.; Bousselmi, K.; Saida B, R.and Allah , M.A (2007). Epiderniological profile and antibiotic susceptibility of Pseudomonas aeruginosa isolated with in burned patient hospitalized in the intensive care burn unit. Tunis Med. 85(2) : 124-127.

16. Singh, U. P. , Prakash, Om., and Ray, A. B.(2001). Antifungal Activity of Withametelin, a Withanolide Isolated from Datura metel . Mycobiology .29(2): 96- .99 .

17. Graciela Andonegui,* Kim Goring,* Dan Liu,* Donna-Marie McCafferty, and Brent W. Winston (2009) Characterization of S pneumoniae pneumonia-induced multiple organ dysfunction syndrome: an experimental mouse model of gram-positive sepsis, shock Vol. 31, No. 4, pp. 423Y428

18. Kaplan V, Angus DC, Griffin MF, Clermont G, Scott WR, LindeZwirble WT: Hospitalized community-acquired pneumonia in the elderly: age- and sexrelated patterns of care and outcome in the United States. Am J Respir Crit Care Med 166:766Y772, 2002.

19. Walsh, T. J. ,W.G. Lee, R. Schaufele, T.Sein, P.O. Whitcomb,M. Ruddel,W. Burns. J.R. Wingrad, A. C. Switchenko, T. Goodman, and P.A.Pizzo.1995.Diagnosis and therapeutic monitoring of invasive candidiasis by rapid enzymatic of serum D-arabinitol. Am. J.Mod. 99:164-172.

20. Siew, F. Y.; Sharon, H.; Andre, N. S.; Sheldon, C.; Amanda,D. and Brian,W.J.(2006). Measurement of Serum d- Arabinitol / Creatinine Ratios for Initial Diagnosis and for 
$\begin{array}{llll}\text { AL-Qadisiya Journal of Vet.Med.Sci. } \quad \text { Vol./12 } & \text { No./1 }\end{array}$

Predicting Outcome in an
Unselected, Population - Based
Sample of Patients with candida
fungemia
.J.Clin.Microbiol.44(11):3894.

21. Achenbach, H. ; Stocher,M.; and Constenla, M. (1988).Flavonoid and other constituents of Bauhinia manca phytochemistry .27:18351841.

22. Chukwurah, B. K. C. (1997). Antimicrobial activity of Holarrhena floribunda stem bark ethanol extract. Fitoterapia 68:180181.
23. Pandey,K.N.(1982).Anitfungal activity of some medicinal plants on stored seeds of Eleusine corocana. Indian phytopathol .35:499-501.

24. Rag haveiah,G.and Jayaramaiah, $M$. (1988). Anitfungal activity of selected plant extract against the white muscardine fungus .Univ. Agril. Sci. Bangalore Curr. Res.17:62-64.

25. Ganguly,L.k.(1994).Fungitoxic effect of certain plant extracts against rice blast and brown spot pathogen . Environ.and ECOL.12:731-733.

\section{تحديد الفعالية العلاجية لمستخلص اوراق الداتورا كمضاد لبعض جراثيم الجهاز

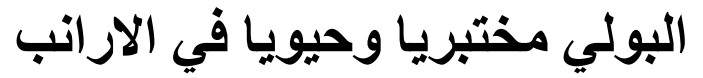 \\ هناء كاظم الموسوي

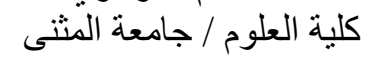 \\ الخلاصة التالة}

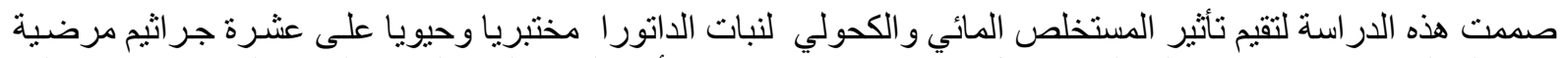

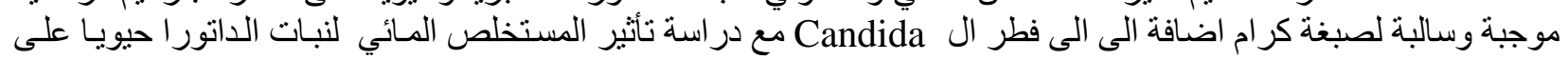

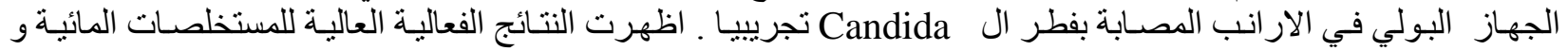

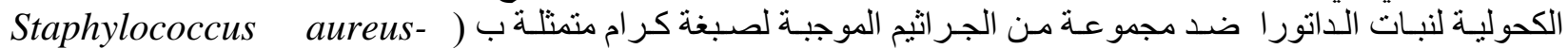
Klebsilla pneumonia -Proteus ) وبعض الجر اثيم السالبة لصبغة كر ام ومتمنلة بـة (Streptococcus agylactiae

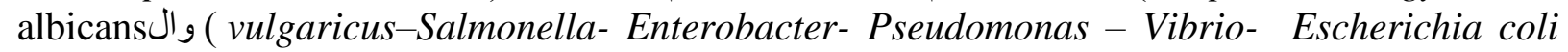

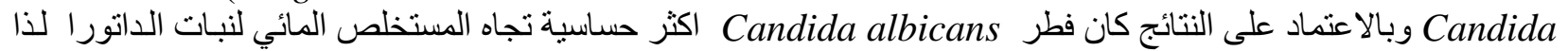

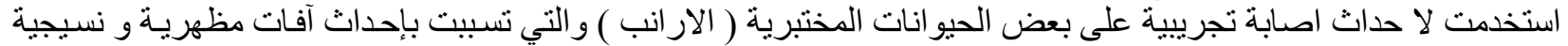

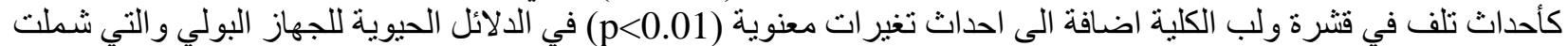

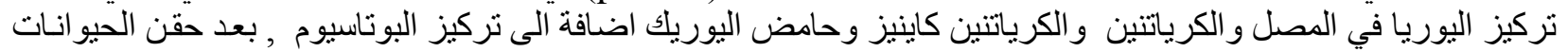

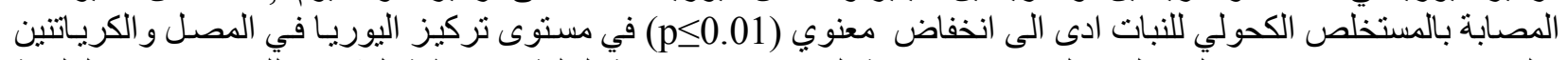

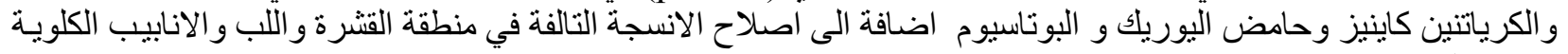
واعادة التنسج من جديد. 